\title{
Steer Gains under Six Systems of Coastal
}

Bermudagrass Utilization

RICHARD H. HART, W. H. MARCHANT, J. L. BUTLER, AND G. W. BURTON

Highlight: Steer gains on 'Coastal' Bermudagrass (Cynodon dactylon (L.) Pers.), utilized by continuous, weekly rotation, or daily strip grazing, or green chop, dehydrated hay, or pellet feeding, were studied for 3 years. Previous studies had included fewer methods of utilization, or had run for only a short time. Average daily gains and gains per hectare were: continuous, $594 \mathrm{~g}$ and $600 \mathrm{~kg}$; rotation, $449 \mathrm{~g}$ and $469 \mathrm{~kg}$; strip, $392 \mathrm{~g}$ and $487 \mathrm{~kg}$; green chop, $369 \mathrm{~g}$ and $647 \mathrm{~kg}$; hay, 671 $\mathrm{g}$ and $971 \mathrm{~kg}$; and pellets, $800 \mathrm{~g}$ and $967 \mathrm{~kg}$. Differences among grazing methods in average daily gain were largely accounted for by differences in grazing pressure. Differences among feeding methods reflected differences in forage intake and lignin content of the forage. Seasonal changes in gain and forage intake were influenced by seasonal changes in lignin content and increasing steer weights.

'Coastal' Bermudagrass (Cynodon dactylon (L.) Pers.), released in 1943, quickly became one of the most important pasture grasses in the southeastern United States and in other areas with similar climate. Continuous grazing, the most common method of using Coastal, has been evaluated at a range of stocking and nitrogen rates, and has produced as much as $1,029 \mathrm{~kg} / \mathrm{ha}$ of beef gain, when $448 \mathrm{~kg} / \mathrm{ha}$ of $\mathrm{N}$ was applied (Suman et al., 1962). Burton (1954) suggested that production might be further increased, perhaps as much as $50 \%$, by daily rotation or strip grazing. Suman et al. (1962) found that weekly rotation grazing of Coastal produced $14 \%$ more gain/ha than continuous grazing when $112 \mathrm{~kg} / \mathrm{ha}$ of $\mathrm{N}$ was applied, but had no advantage at higher rates of nitrogen.

Although rotation grazing was first recommended in print in 1598 (Smith, 1956), both Wheeler (1962) and Blaser et al. $(1973,1974)$ noted that few studies had shown any advantage of rotation over continuous grazing. Blaser et al. pointed out that continuous grazing allows for greater forage selection by the grazing animal, an important consideration in grazing warmseason grasses, which tend to lose quality rapidly with increasing maturity. They also stated that the low availability of forage at the end of a rotation grazing period depresses gains and reduces total forage production. McMeekan (1960) and Wheeler noted that when an advantage was found for rotation or strip grazing, those pastures were stocked more heavily than the

Authors are agronomist, U.S. Department of Agriculture, Agricultural Research Service; agronomist, University of Georgia; agricultural engineers, U.S. Dep. Agr., Agr. Res. Serv.; animal scientists, University of Georgia; and geneticist, U.S. Dep. Agr., Agr. Res. Serv.. Coastal Plain Experiment Station, Tifton, Georgia 31794.

Hart's present address is U.S. Dep. Agr., Agr. Res. Serv., High Plains Grasslands Research Station, Cheyenne, Wyoming 82001; Southwell is now retired.

This report results from cooperative investigations of the U.S. Dep. Agr., Agr. Res Serv., and the Univ. of Georgia, College of Agriculture Exp. Sta., Coastal Plain Exp. Sta. Manuscript received October 2, 1975
R. E. HELLWIG, W. C. MCCORMICK, B. L. SOUTHWELL,

continuously grazed pastures. McMeekan concluded that, if both systems were stocked equally, rotation grazing would produce higher gains or milk production only at high stocking rates. However, high stocking rates increase forage waste from trampling and from fouling with dung and urine.

The problem of high stocking rate can be avoided by mechanical harvesting of forage. Brown (1961) nearly doubled average daily gain and gain/ha by feeding Coastal Bermudagrass as soilage instead of grazing it continuously. At the Southeast Georgia Branch Station, steers made average daily gains of 467, 476, 621, and $943 \mathrm{~g}$, respectively, from Coastal used as soilage, hay, continuous grazing, and pellets (Beaty et al., 1960; and Hogan et al., 1962), but this test was conducted for only 60 days. Other workers have reported higher average daily gain on pellets than on hay (Brooks et al., 1962) or pasture (Chapman et al., 1972).

Previous studies had been concerned with only a few methods of using Coastal Bermudagrass, or had been conducted for only a short time. In 1960, we decided to initiate a 3-year experiment which would include most of the possible methods of using Coastal. The methods, in order of increasing intensity of management, were continuous grazing, rotational grazing with cattle moved to fresh pasture weekly, strip grazing with cattle moved daily, green chop or soilage with grass cut and fed daily, chopped dehydrated hay, and pellets made from chopped dehydrated hay. All treatments except continuous grazing were to be managed so that cattle would be eating grass approximately 4 weeks old.

\section{Materials and Methods}

Coastal Bermudagrass was sprigged on 16.2 ha of Tifton fine sandy loam in July and August, 1960. In 1961, the area was fertilized with 224,25 , and $93 \mathrm{~kg} / \mathrm{ha}$ of N, P, and K, respectively, and two cuttings of hay were taken, totalling about 11 ton/ha. In early spring of 1962 , the area was subdivided into 24 paddocks of 0.67 ha, in four replications of six paddocks each. One-half of each replication was fenced, to be used for grazing; the remaining half, to be used for green chop, hay, and pellets, was left unfenced.

Electric fences were installed to limit the grazing areas on the strip and rotation grazing treatments. Permanent concrete watering troughs were placed in the continuously grazed paddocks, and portable metal watering cups, supplied by plastic hoses, were used in the strip and rotationally grazed paddocks. In 1962, these paddocks were divided into quarters; if cattle did not graze the entire quarter during a week, they were moved to the next quarter, and the ungrazed area was mowed, the forage removed, and dry matter yield determined. Occasionally, when forage supply was low, a quarter was grazed in 
Table 1. Management of the experiment and initial weight of steers.

\begin{tabular}{clrrr}
\hline \hline Management & Treatment & 1962 & 1963 & 1964 \\
\hline Fertilizer (kg/ha) & & & & \\
N & All & 224 & 224 & 280 \\
P & All & 25 & 25 & 25 \\
K & Grazed & 93 & 93 & 93 \\
& Harvested & 93 & 93 & 149 \\
Grazing and & & & & \\
feeding dates & & & & \\
Began & Grazed & May 9 & Apr. 18 & Apr. 22 \\
\multicolumn{1}{c}{ Ended } & Harvested & May 30 & May 7 & May 20 \\
& Grazed & Oct. 12 & Sept. 5 & Sept. 16 \\
\multicolumn{1}{c}{ Days } & Harvested & Oct. 24 & Sept. 5 & Sept. 16 \\
& Grazed & 156 & 140 & 147 \\
Initial weight (kg) & Harvested & 147 & 121 & 119 \\
\hline
\end{tabular}

less than a week. In 1963 and 1964, this subdivision was abandoned; the grazing area was moved across a paddock for 4 weeks, or less if the grass was exhausted sooner, and then was returned to the starting point. Any remaining ungrazed forage was harvested.

Five steers were allotted to each paddock ( 7.4 steers/ha), except from July 23 to October 11,1962 , when drouth forced us to remove two or three steers from each grazed paddock. On rotation and strip grazing, yields of the area to be grazed next were used to determine the size of the area to be allotted. We allotted $7.3 \mathrm{~kg}$ dry matter per steer per day at the beginning of each season, and graduallyincreased this to $13.5 \mathrm{~kg}$ at the end of the season, as steer weight increased and forage quality decreased.

The paddocks providing harvested forage were divided into quarters in 1962. Green chop was cut daily for a week or until all had been cut from the appropriate quarter; then forage was cut from any remaining area and harvest began in the next quarter. In 1963 and 1964, paddocks were not subdivided; harvesting continued across each paddock for up to 4 weeks, and only then was surplus forage harvested. In 1962, hay and pellets were made weekly from one-fourth of each paddock; in 1963 and 1964, they were made every 4 weeks from the whole paddock. A forage harvester, set to cut forage into $8-\mathrm{mm}$ lengths, cut the grass for green chop, hay, and pellets, leaving a 4-cm stubble, and blew it into a self-unloading wagon. Forage to be fed as hay was put through a drier rated to evaporate $2,700 \mathrm{~kg}$ /hour of water, and bagged. Forage for pellets was dehydrated and ground in a hammermill, through a $3.2-\mathrm{mm}$ screen. Water was added as needed, partly in the form of steam, and the material was pelleted with a 50-hp California Pellet Mill, Standard Model, through a die having straight bore holes $9.5-\mathrm{mm}$ in diameter and $6.4-\mathrm{cm}$ long. The pellets, extruded at a temperature of about $71^{\circ} \mathrm{C}$, were elevated into a cooler, cooled to ambient temperature, scalped, and bagged. The scalped fines were returned to the pellet mill hopper by a screw conveyor.

Steers fed harvested forage were grazed on Coastal Bermudagrass until feeding started. Each group of five steers fed hay or pellets was placed in a lot approximately $9 \times 38-\mathrm{m}$, with a trough $7-\mathrm{m}$ long under a shelter at one end. The steers fed green chop were in lots twice as big, with twice as much trough space. The stecrs were fed each morning. Green chop, hay, or pellets were weighed into the troughs, in amounts well in excess of daily consumption, after refused material was weighed out. Samples were taken for the determination of dry matter and, in the case of the forage as fed, crude protein, ether extract, cellulose, lignin, other carbohydrates, and ash. Green chop, both as fed and refused, was sampled daily; hay and pellets were sampled weekly. Forage intake was estimated by difference, with no allowance for waste.

All cattle were sprayed regularly to control horn flies, and were weighed every 4 weeks. Grass was burned every spring to control spittlebug, and the grazed paddocks were dragged with a tine harrow to break up manure piles from the year before. Fertilization of the paddocks, beginning and ending dates of grazing and feeding, and initial weights of the steers in each year are shown in Table 1.

\section{Results and Discussion}

Stocking rates, grazing pressures, and animal performance under each system in each year are shown in Table 2. Forage production varied from year to year; mean dry matter yields from the paddocks cut for hay and pellets werc 12.8, 11.0, and 11.1 tons/ha in 1962, 1963, and 1964, respectively. Stocking rate on the grazed paddocks also varied; we removed some of the cattle in 1962 because of drouth, and we varied the size of the daily or weekly allotment of grass on strip and rotation grazing, according to yield and season. Therefore, grazing pressure, expressed as animal days/ton of harvested forage dry matter, was different each year on cach treatment. However, it was generally lightest under continuous grazing; slightly heavier under rotation and strip grazing and pellet feeding; still heavier when hay was fed; and heaviest on green chop.

Under grazing, average daily gain (ADG) was strongly and negatively correlated with grazing pressure (Fig. 1). If we assume ADG on pellets was an estimate of the maximum performance of which the steers fed in that year were capable (as determined by initial weight, previous level of gain, genetic potential, etc.), and express the ADG under grazing in percent of this assumed maximum, we can remove the effects of

Table 2. Stocking rate, grazing pressure, forage intake, and steer gains on Coastal Bermudagrass.

\begin{tabular}{|c|c|c|c|c|c|c|c|}
\hline \multirow[b]{2}{*}{ Measurement } & \multirow[b]{2}{*}{ Year } & \multicolumn{3}{|c|}{ Grazed } & \multicolumn{3}{|c|}{ Harvested } \\
\hline & & Continuous & Rotation & Strip & Green chop & Hay & Pellets \\
\hline Animal days/ha & $\begin{array}{l}1962 \\
1963 \\
1964\end{array}$ & $\begin{array}{r}890 \\
1048 \\
1090\end{array}$ & $\begin{array}{r}896 \\
1129 \\
1155\end{array}$ & $\begin{array}{l}1311 \\
1273 \\
1151\end{array}$ & $\begin{array}{l}1742 \\
1925 \\
1553\end{array}$ & $\begin{array}{l}1712 \\
1289 \\
1419\end{array}$ & $\begin{array}{l}1361 \\
1140 \\
1161\end{array}$ \\
\hline Animal days/ton of forage dry matter & $\begin{array}{l}1962 \\
1963 \\
1964\end{array}$ & $\begin{array}{l}70 \\
95 \\
98\end{array}$ & $\begin{array}{r}70 \\
103 \\
104\end{array}$ & $\begin{array}{l}103 \\
116 \\
104\end{array}$ & $\begin{array}{l}137 \\
175 \\
140\end{array}$ & $\begin{array}{l}134 \\
117 \\
128\end{array}$ & $\begin{array}{l}107 \\
104 \\
105\end{array}$ \\
\hline Intake (kg dry matter/steer/day) & $\begin{array}{l}1962 \\
1963 \\
1964\end{array}$ & $\begin{array}{l}- \\
- \\
-\end{array}$ & $\begin{array}{l}- \\
- \\
-\end{array}$ & $\begin{array}{l}- \\
- \\
-\end{array}$ & $\begin{array}{l}6.3 b^{1} \\
6.1 b \\
6.1 b\end{array}$ & $\begin{array}{l}6.9 \mathrm{ab} \\
7.9 \mathrm{a} \\
8.3 \mathrm{a}\end{array}$ & $\begin{array}{l}8.2 \mathrm{a} \\
8.5 \mathrm{a} \\
8.9 \mathrm{a}\end{array}$ \\
\hline Average daily gain (g) & $\begin{array}{l}1962 \\
1963 \\
1964\end{array}$ & $\begin{array}{l}599 \mathrm{ab} \\
567 \mathrm{c} \\
617 \mathrm{~b}\end{array}$ & $\begin{array}{l}535 \mathrm{~b} \\
422 \mathrm{~d} \\
390 \mathrm{c}\end{array}$ & $\begin{array}{l}331 \mathrm{c} \\
445 \mathrm{~d} \\
399 \mathrm{c}\end{array}$ & $\begin{array}{l}268 \mathrm{c} \\
458 \mathrm{~cd} \\
381 \mathrm{c}\end{array}$ & $\begin{array}{l}508 \mathrm{~b} \\
730 \mathrm{~b} \\
776 \mathrm{a}\end{array}$ & $\begin{array}{l}667 a \\
880 a \\
853 a\end{array}$ \\
\hline Gain/ha (kg) & $\begin{array}{l}1962 \\
1963 \\
1964\end{array}$ & $\begin{array}{l}533 b \\
594 b \\
673 c\end{array}$ & $\begin{array}{l}479 \mathrm{~b} \\
476 \mathrm{~b} \\
451 \mathrm{e}\end{array}$ & $\begin{array}{l}434 \mathrm{~b} \\
566 \mathrm{~b} \\
460 \mathrm{e}\end{array}$ & $\begin{array}{l}467 \mathrm{~b} \\
882 \mathrm{a} \\
592 \mathrm{~d}\end{array}$ & $\begin{array}{r}870 \mathrm{a} \\
942 \mathrm{a} \\
1101 \mathrm{a}\end{array}$ & $\begin{array}{r}908 \mathrm{a} \\
1003 \mathrm{a} \\
990 \mathrm{~b}\end{array}$ \\
\hline
\end{tabular}

${ }^{1}$ Utilization system means in the same year, followed by the same letter, are not significantly different (Duncan's multiple range test, $5 \%$ level of probability). 
196218631964

\section{Cont. Rot. Strip}

ADG, relative

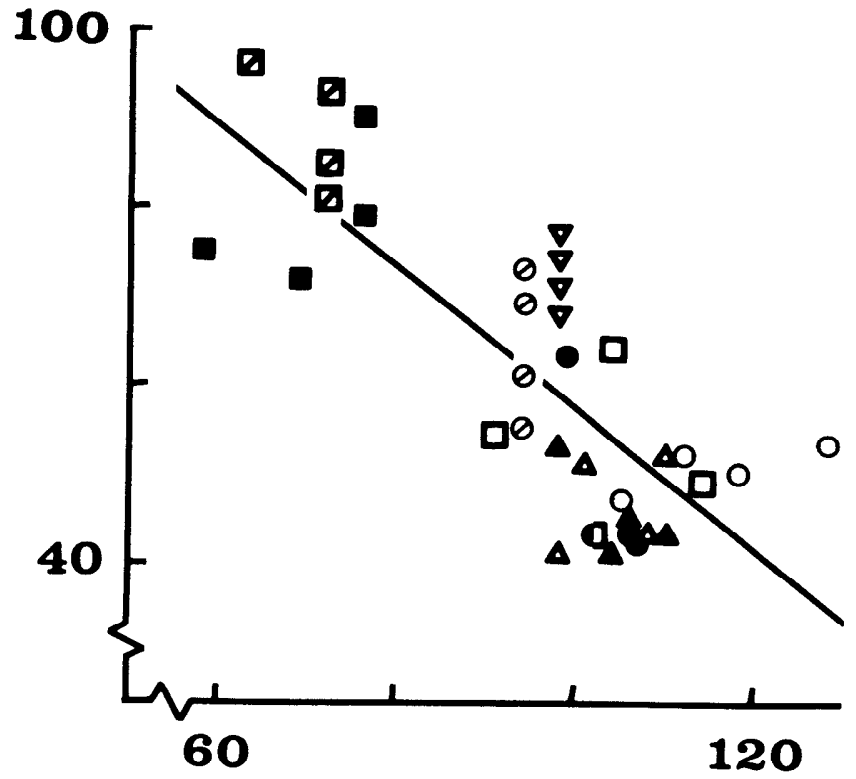

Animal days/MT forage DM

Fig. 1. Grazing pressure (animal days/metric ton of forage dry matter) and relative average daily gain ( $A D G)$ of steers grazing Coastal Bermudagrass.

differences among the lots of steers used in the different years. This relative ADG was predicted by the equation

$$
\mathrm{ADG}=140-0.795 \mathrm{D} / \mathrm{F} \text {, }
$$

in which $\mathbf{D} / \mathbf{F}$ equals animal days/ton harvested forage dry matter; $\mathbf{r}^{2}=0.60$. This equation is a modification of the model proposed by Hart (1973) and confirmed and further developed by Jones and Sandland (1974). Analysis of covariance indicated

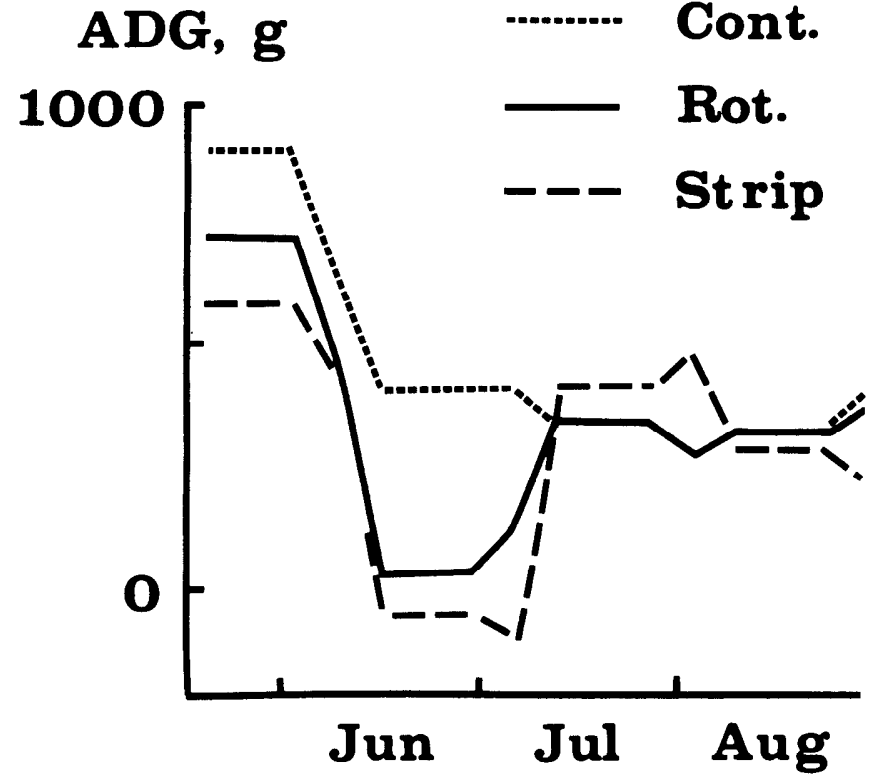

Fig. 2. Seasonal variation in average daily gain $(A D G)$ of steers grazing Coastal Bermudagrass.

no significant differences in ADG among grazing treatments in 1962 and 1963, after the effect of differential grazing pressure was removed. In 1964, ADG on continuous grazing remained significantly higher than that on rotation or strip grazing, after grazing pressure effect was removed, although grazing pressure was only $6 \%$ higher on rotation and strip than on continuous grazing. Therefore, we concluded there was no evidence that rotation or strip grazing produced higher average daily gains than continuous grazing, at equal grazing pressures or stocking rates.

ADG of steers fed green chop was consistently low, as was forage intake. We thought intake might be increased by feeding twice a day, so we tried it with two of the four lots of steers for two weeks in 1963. During the test period, steers fed twice daily ate $5 \%$ more than steers fed once daily, but they also ate $2 \%$ more in the 2 weeks before the test, and $4 \%$ more in the 2 weeks after the test. Intake was not improved by feeding twice a day.

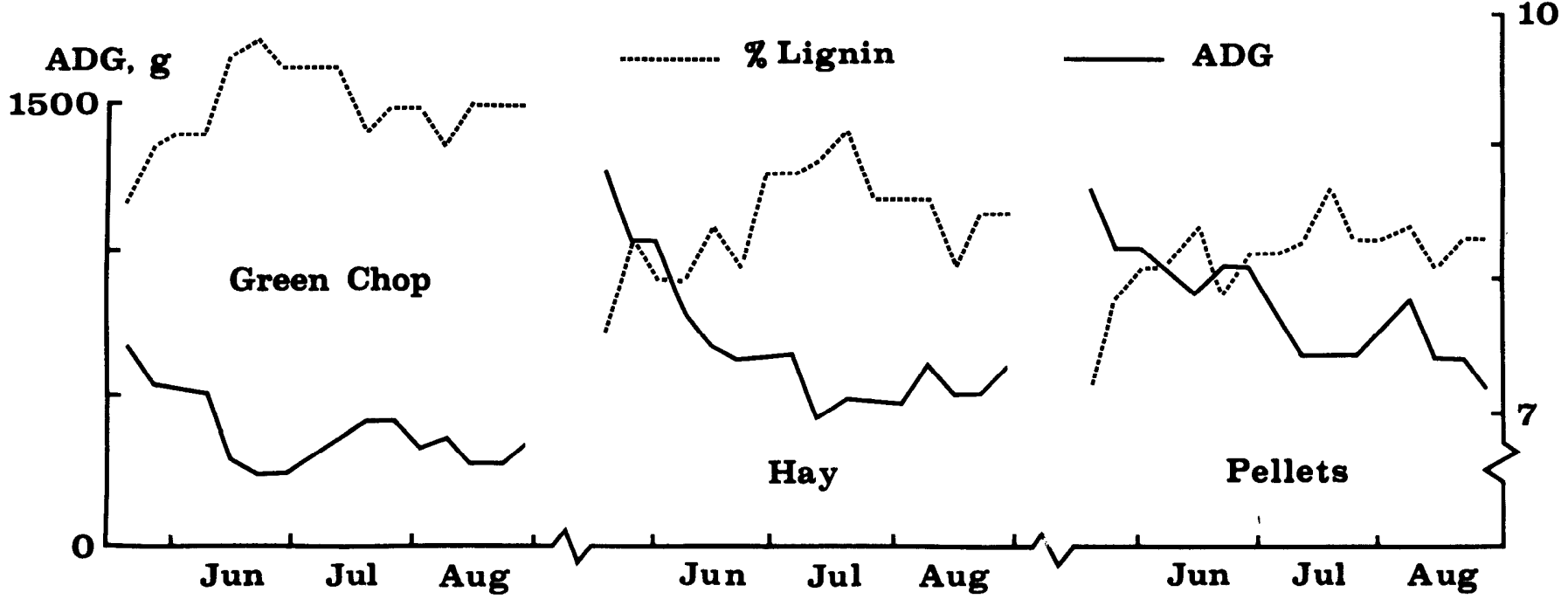

Fig. 3. Seasonal variation in average daily gain (ADG) of steers fed Coastal Bermudagrass, and in the lignin content of the forage. 
The low forage intake made it possible to carry more steers/ha on green chop than on any other system, but gain/ha remained low. Hay and pellet feeding produced significantly higher ADG and gains/ha than continuous grazing, but the value of the additional gain must be balanced against the costs of harvesting, processing, storing, and feeding.

Mean weekly gains for a 14-week period are shown in Figures 2 and 3 . We included only those weeks for which we had 3 years' data, but omitted weeks at the end of the season if the last weigh period was less than 4 weeks in any year. ADG of steers on grazing or green chop showed a marked slump in late June and early July; this coincided with an increase in the lignin content of the harvested forage (grazed paddocks were not sampled, because it was not possible to select forage corresponding to that actually eaten by the cattle). The same increase in lignin and slump in ADG occurred a few weeks later when hay and pellets were fed, because of the delay imposed by harvesting, processing, and storing before feeding. This pattern of gain and lignin content is similar to that reported by Beaty et al. (1966) and Hawkins and Rollins (1960). Forage availability influenced the level of response, but did not change the seasonal pattern.

Lignin content of hay was slightly higher than that of pellets, and that of green chop was much higher still, although there was no apparent reason for the differences. ADG, both within and among feeding systems, was highly correlated with percent lignin (L). Across all three feeding systems,

$\mathbf{r}^{2}=0.77$.

$$
\mathrm{ADG}=3976-388 \mathrm{~L} \text {; }
$$

Intake of green chop, hay, or pellets was correlated with lignin content, but this relationship was obscured because intake increased throughout the season as steer weight increased. With steer weights in $\mathrm{kg}(\mathrm{W})$ as the only variable, intake in $\mathrm{kg} / \mathrm{steer} /$ day, or I, was predicted by the equation

$$
\mathrm{I}=0.0397 \mathrm{~W}-4.23 \text {; }
$$

$\mathbf{r}^{2}=0.61$. Including lignin content $(\mathrm{L})$ in the equation changed it to

$$
\mathrm{I}=0.0307 \mathrm{~W}-1.071 \mathrm{~L}+7.74 \text {; }
$$

$\mathbf{R}^{2}=0.89$, which represents a $71 \%$ decrease in unaccounted-for variation.

Crude protein content showed no consistent seasonal pattern.
Neither intake nor gains were significantly correlated with any chemical fraction other than lignin.

\section{Literature Cited}

Beaty, E. R., D. D. Hayes, and E. E. Worley. 1966. Effect of season of harvesting Coastal Bermudagrass on rumen dry-matter disappearance, bulk density, and animal gains. Proc. 10th Int. Grassl. Congr. p. 921-923.

Beaty, E. R., R. A. McCreery, and O. L. Brooks. 1960. Relationship between the physical form of roughage and animal performance. Proc. 8th Int. Grassl. Congr. p. 708-710.

Blaser, R. E., D. D. Wolf, and H. T. Bryant. 1973. Systems of grazing man agement. In: Heath, M. E., D. S. Metcalfe, and R. F. Barnes (Eds.). Forages, 3rd ed., p. 581-595. Iowa State University Press, Ames.

Blaser, R. E., E. Jahn, and R. C. Hammes, Jr. 1974. Evaluation of forage and animal research. In: VanKeuren, R. W. (Ed.). Systems analysis in forage crops production and utilization, p. 1-26. Crop Sci. Soc. Amer., Madison, Wis.

Brown, R. H., E. R. Beaty, R. A. McCreery, and J. D. Powell. 1961. Coastal Bermudagrass utilization. Soilage vs continuous grazing. J. Range Manage. 14:297-300.

Brooks, O. L., W. J. Miller, E. R. Beaty, and C. M. Clifton. 1962. Performance of dairy cows fed pelleted and baled Coastal Bermudagrass and alfalfa hay. J. Dairy Sci. 45:1188-1191.

Burton, G. W. 1954. Coastal Bermudagrass. Georgia Agr. Exp. Sta. Bull. N. S. 2. 31 p.

Chapman, H. D., W. H. Marchant, P. R. Utley, R. E. Hellwig, and W. G. Monson. 1972. Performance of steers on Pensacola Bahiagrass. Coastal Bermudagrass and Coastcross-1 Bermudagrass pastures and pellets. J. Anim. Sci. 34:373-378.

Hart, R. H. 1973. Forage yield, stocking rate, and beef gains on pasture. Herb Abstr. 42:345-353.

Hawkins, G. E., and G. H. Rollins. 1960. Intake and digestibility of Coastal Bermudagrass and Bahiagrass as affected by management. J. Dairy Sci. 43:444-445.

Hogan, W. H., O. L. Brooks, E. R. Beaty, and R. A. McCreery. 1962. Effect of pelleting Coastal Bermudagrass on livestock gains. Agron. J. 54:193-195.

Jones, R. J., and R. L. Sandland. 1974. The relation between animal gain and stocking rate. Derivation of the relation from the results of grazing trials. $J$. Agr. Sci. (Camb.) 83:335-342.

McMeekan, C. P. 1960. Grazing management. Proc. 8th Int. Grassl. Congr. p. 21-26.

Smith, J. H. 1956. Some early advocates of rotational grazing. J. Brit. Grassl. Soc. 11:199-202.

Suman, R. F., S. G. Woods, T. C. Peele, and E. G. Godbey. 1962. Beef gains from differentially fertilized summer grasses in the Coastal Plain Agron. J. 54:26-28.

Wheeler, J. L. 1962. Experimentation in grazing management. Herb. Abstr. 32:1-7.

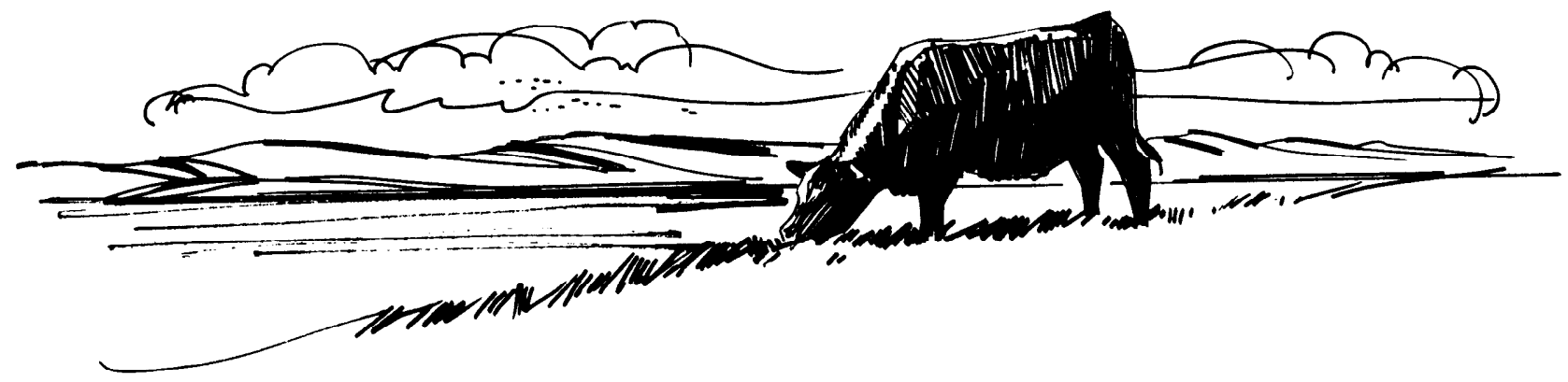

